\title{
Multimethod teaching strategies to integrate selected QSEN competencies in a Doctor of Nursing Practice distance education program
}

Mary Lou Manning, PhD, CRNP

Thomas Jefferson University

Anthony J. Frisby, PhD

Thomas Jefferson University

Follow this and additional works at: https://jdc.jefferson.edu/nursfp

Part of the Nursing Administration Commons, and the Other Nursing Commons

Let us know how access to this document benefits you

\section{Recommended Citation}

Manning, PhD, CRNP, Mary Lou and Frisby, PhD, Anthony J., "Multimethod teaching strategies to integrate selected QSEN competencies in a Doctor of Nursing Practice distance education program" (2011). College of Nursing Faculty Papers \& Presentations. Paper 45.

https://jdc.jefferson.edu/nursfp/45

This Article is brought to you for free and open access by the Jefferson Digital Commons. The Jefferson Digital Commons is a service of Thomas Jefferson University's Center for Teaching and Learning (CTL). The Commons is a showcase for Jefferson books and journals, peer-reviewed scholarly publications, unique historical collections from the University archives, and teaching tools. The Jefferson Digital Commons allows researchers and interested readers anywhere in the world to learn about and keep up to date with Jefferson scholarship. This article has been accepted for inclusion in College of Nursing Faculty Papers \& Presentations by an authorized administrator of the Jefferson Digital Commons. For more information, please contact: JeffersonDigitalCommons@jefferson.edu. 


\section{As submitted to: \\ Nursing Outlook}

\section{And later published as:}

\section{Multi-method teaching strategies to integrate selected QSEN competencies in a Doctor of Nursing Practice distance education program}

\section{Volume 59, Issue 3, Pages 166-173 (May 2011) doi:10.1016/j.outlook.2011.01.001}

Mary Lou Manning PhD, CRNP

Associate Professor

Director, Doctor of Nursing Practice Program

Jefferson School of Nursing

Thomas Jefferson University

Philadelphia, PA

Anthony J. Frisby, PhD

Associate Professor, Family and Community Medicine

Jefferson Medical College

Director, Education Services, Academic \& Instructional Support and Resources

Thomas Jefferson University

Philadelphia, PA

\section{Abstract}

The Quality and Safety Education for Nurses (QSEN) initiative identified six competencies for the education of nurses (patient centered care, teamwork and collaboration, evidence-based practice, quality improvement, safety, and informatics) and the related knowledge, skills, and attitudes (KSAs) for each competency. The initial 
QSEN focus was on competency development during pre-licensure nursing education, with subsequent attention on adapting the KSAs for graduate programs that prepare advanced practice nurses for clinical roles. Description of successful QSEN competency integration in Doctor of Nursing Practice (DNP) programs is limited. While the ultimate goal is executing DNP programs where quality and safety is thoroughly integrated throughout the curricula, the focus of this article is on multi-method teaching strategies to integrate selected QSEN KSA's into an existing online post-Master's DNP quality and safety course.

\section{Introduction}

In 2004 the American Association of Colleges of Nursing (AACN) endorsed the Doctor of Nursing Practice (DNP) degree as the terminal degree for advanced nursing practice. The AACN The Essentials of Doctoral Education for Advanced Nursing Practice ${ }^{1}$ guide DNP curricula with an emphasis on programmatic content related to evidence-based practice, quality improvement, and leadership within a systems perspective. As of August 2010 there were 227 institutions in 37 states and the District of Columbia offering or planning DNP programs..$^{2}$

In 2003 the Institute of Medicine (IOM) in a report, Health Professions Education: A Bridge to Quality $^{3}$ identified five core competencies that all health disciplines should possess, namely: provide patient centered care, work in interdisciplinary teams, employee evidence-based practice, apply quality improvement and utilize informatics. In response to this and related IOM reports the Quality and Safety Education for Nurses (QSEN) initiative, funded by the Robert Wood Johnson Foundation, was launched to inform and 
guide integration of quality and safety competencies in nursing education. The QSEN faculty and national advisory board, with representatives from national nursing organizations, added a sixth competency domain titled safety, as well as defined competency related knowledge, skills, and attitudes (KSAs) needed to practice effectively within the complex health care environment. The initial QSEN focus was competency development during pre-licensure nursing education, followed by suggested adaptation for graduate and practice doctorate nursing education. ${ }^{4-6}$

The QSEN competencies are consistent with, and embedded in the AACN DNP Essentials. ${ }^{1}$ The challenge is to utilize multi-method strategies to support robust integration of these concepts throughout DNP curricula in a manner encouraged by Pohl and colleagues. ${ }^{6}$ This article describes the use of multiple methods to integrate QSEN KSA's into an existing online course. Multi-media, more specifically, student team produced educational videos, provided the vehicle for experiential learning, interpretative thinking, reflective practice and peer-review to facilitate DNP student achievement of selected advanced QSEN competencies.

\section{Background}

Our School of Nursing began offering a post-masters DNP online distanceeducation program in 2007 and two years later received accreditation from the Commission on Collegiate Nursing Education. The Health Care Quality and Patient Safety (HCQPS) 15-week asynchronous online DNP course was offered for the second time in fall 2009. Sixteen advanced practice nurses, with clinical expertise spanning primary, acute and chronic care, school health and organization of care, were enrolled in the course. The students had completed 5 of the 12 required courses making them 
experienced with distance education, Blackboard (the online learning system), discussion boards, library resources and services, and effective mechanisms for contact and dialogue with peers and faculty. Interestingly, all students were familiar with the AACN DNP Essentials, but none were familiar with QSEN.

The HCQPS course objectives were based on the AACN DNP Essentials and QSEN competencies with emphasis on advanced teamwork and collaboration, evidencebased practice, safety, quality improvement, and informatics. The assigned course readings, PowerPoint presentations combined with an audio component, video clips, and related discussion boards and assignments helped students advance KSAs related to the nature of error and harm in healthcare, organizational culture, systems theory, error reduction strategies and tools, measurement, the business case for quality, teamwork, communication, and the QSEN initiative. Readings from the Agency for Healthcare Research and Quality's Patient Safety and Quality: An Evidence-based Handbook for Nurses $^{7}$ furnished valuable insights from national experts.

Realizing the importance of advancing the QSEN competencies and the potential impact that the DNP students had to influence healthcare quality and patient safety, a new fast paced, creative assignment, combining an evidence based review with an experiential informatics/technology component replaced a previous assignment as a course requirement. The assignment, student team produced educational videos, provided the vehicle for students to:

- acquire a comprehensive, evidence-based understanding of a patient safety topic,

- consult with stakeholders and subject matter experts, 
- distill a complex topic into a short educational video production targeted to a selected audience,

- discover the role of multi-media technology in effective message design,

- utilize advanced communication techniques and,

- cultivate interpretive thinking.

The new assignment created the opportunity for online DNP students to critically analyze, synthesize, and evaluate information, resources and technology and together apply it to creating compelling messages for a defined population. Epstein and colleagues $^{8}$ used student team produced videos to replace individual student case study assignments. They report that students responded with enthusiasm to the new challenge and the opportunity to take a more creative role in their own learning.

Students were informed of the educational video production requirement on the first day of class via the online course board and a teleconference course orientation. The video was due during the thirteenth week of the course.

Theoretical Foundation

The QSEN competencies of advanced teamwork and collaboration and advanced informatics literacy, represent areas that are difficult to convey (through online readings or discussion), or measure (through student writing of scholarly papers). The advancement of these competencies by DNP students requires a problem-based, interactive, experiential learning environment, as postulated in adult learning theory. ${ }^{9}$ Experiential learning, the main source of working or "how to" knowledge, ${ }^{10}$ is ideally suited for experienced clinicians, for according to $\mathrm{Kolb}^{11}$ such learning pursues a framework for examining and strengthening the critical linkages among education, work 
and personal development. As a result learners transform experiences into existing cognitive frameworks, changing the way they think and behave. Benner and colleagues ${ }^{12}$ indicate that experiential learning requires environments rich in performance feedback and deliberately planned opportunities for learner expression and reflection.

Similarly, constructivist pedagogy suggests that learners actively create knowledge by testing ideas, concepts and approaches based on existing knowledge and experience, while acknowledging multiple, socially constructed truths, perspectives, and realities. ${ }^{13-15}$ Legg and colleagues ${ }^{13}$ examined the theory's applicability to online distance education and found constructivism allows learners to take control of their learning, and educators to facilitate and guide learning. Hunter and $\mathrm{Krantz}^{14}$ report similar findings related to a graduate nursing online course on cultural diversity and Hughes, Ventura and Dando $^{15}$ illustrate the theory's application to online, interprofessional education. Narrative pedagogy, with its emphasis on how students learn and experience thinking, is also a befitting framework for DNP student course work, as they are encouraged to pool their wisdom, challenge their preconceptions, envision new possibilities and engage with others. $^{16-17}$

\section{Student Video Productions}

Video production consisted of three, learner-centered, faculty-guided phases:

(1) formative phase to acquire a comprehensive understanding of the issue to determine the video purpose, objectives, audience and format,

(2) production phase to consult and collaborate with subject matter and video production experts, and produce the video and, 
(3) evaluation phase consisting of peer review, student narrative reflection and faculty evaluation of student work.

The course faculty decided, after much deliberation, that rather than have students select their own topics, one topic would be assigned. This was the first time such an assignment was required, making it difficult to predict resources and student-faculty time commitments. It also allowed standardization of peer review and faculty evaluation. Hand hygiene was the selected topic. Numerous factors influenced this decision including: 1) hand hygiene is a multi-dimensional topic having implication across all settings and populations, allowing for a creative, learner-centered approach, 2) all students had significant experience with the topic, 3) hand hygiene has long been regarded as the most effective measure to prevent or reduce risk of transmission of infectious agents and the consistent practice among health care providers is associated with reduction in the incidence of health care associated infections, establishing it as an important patient safety intervention, ${ }^{18-19}$ 4) sufficient evidence existed linking the practice to patient outcomes, 5) the World Health Organization had recently launched its first Global Patient Safety Challenge titled Clean Care is Safer Care designed to galvanize action for hand hygiene at the point of care, ${ }^{20} 6$ ) hand hygiene compliance is considered a major infection control challenge in health care settings as well as school, college and community settings, ${ }^{21}$ and 7) hand hygiene was on the minds of the local, regional and national groups due to the $\mathrm{H} 1 \mathrm{~N} 1$ influenza epidemic.

\section{Formative Phase}


Students organized into seven self-selected teams of two to three students. Students from the same organization or geographic location were encouraged to work together to produce a video for a designated institution or organization.

Working remotely from each other, students became increasingly technologically savvy as they "met" via the web. Class discussion boards and team group pages were launched to facilitate student, team and faculty interaction. The project began with students completing an extensive literature review. Hand hygiene guidelines and systematic reviews were placed in a folder on the course board providing students a starting point. Faculty facilitated consultative teleconferences giving each team time to explore ideas, seek peer feedback and have questions answered. Video planning tips were posted to the course board, reviewed with students during teleconferences and online discussion boards. During the second week of class each team submitted a one-page narrative identifying team member responsibilities, proposed video purpose and objectives, audience, timeline and team communication plan. Team progress reports were required every two weeks outlining the script, operational details and potential barriers. Faculty provided feedback on each report and increasingly encouraged the teams to use their collective knowledge, experience and resources to envision the video impact on the identified populations. Students were able to contact faculty in person, by email or phone. The University Learning Resource Center stood poised to provide expertise, equipment, and technical support, as requested.

\section{Production Phase}

Each student team independently led its own production. Faculty was available, if needed, for technical or content consultation. Students used online collaborative 
technologies to plan and coordinate the production, electronic storyboards to outline the scenes and filming sequence, and video elements of music, graphics, video clips, still images, interviews and narration. Faculty recognized that students had varying degrees of skill with and access to video production equipment. Initially these potential differences in skills gave us some concern. However, similar to the reported experiences of Epstein ${ }^{8}$, students actually sought very little help from campus support groups identified to assist them. Students were encouraged to contact and utilized workplace multi-media department if such a resource existed. Video cameras and editing equipment were available in the University Learning Resources Centers. Students were reminded that many cell phones and digital cameras are also able to record video. For editing, students were reminded that many new computers already have movie making software that has been loaded by the manufacturer. Windows computers typically have Windows Movie Maker and many Macs will have iMovie software. For students not having movie making software on their computer they were encouraged to search Download.com which has many free software programs including video editors. Financial support was not available. Students handdelivered, mail (return receipt requested) or shipped their final video to designated faculty in the University's Academic and Instructional Support Resources Education Services group for loading into the course.

Most teams used Windows Movie Maker and iMovie software. One team created their video through computer graphics and, using Quicktime, converted into a movie format. Seven compelling 5-minute videos were created that focused on hand hygiene and interprofessional clinical teams, nurses across practice settings, multi-lingual hospital visitors, special needs students, and elementary and preschool children. 


\section{Evaluation Phase}

Evaluation methods were selected based on experiential, constructivist, narrative and conventional pedagogies. ${ }^{11,13-17}$ Collectively, the frameworks propose learner engagement through ownership, active participation, idea testing, peer-review, and reflection related to content and learning process.

\section{Peer Review}

Peer review is common in both the academic and healthcare environments for practitioners and increasingly in student evaluations. ${ }^{22-24}$ The approach has been used in asynchronous, online education to involve students in the evaluation process. ${ }^{15}$ Students find the peer review process challenging, as it makes them think more critically, as well as reflect on their own performance. ${ }^{21}$

Videos with the associated objectives were placed in a folder on the course board. Students had one week to view the videos and complete the faculty developed peer review tool for each video. The tool, shown in Table 1, consisted of seven questions with comment sections, related to the assignment objectives. The narrative comments indicated that the students were "amazed" by how the different teams interpreted the assignment guidelines, as well as the diversity of approaches taken to complete the assignment.

Boehm and Bonnel ${ }^{25}$ describe the process of peer review and summarize research in the literature that document the anxiety peer review can induce in students. To help manage this anxiety, the reviews were posted by each student to the course board assignment page and kept anonymous. Anonymity encouraged reviewers to provide appropriate criticism and hopefully made the peer review a non-threatening process. 
Faculty collated the peer review responses and shared and discussed the results with each student group. The three groups receiving the highest peer review scores were recognized in the form of congratulatory messages on the course board and "video award" certificates mailed to their homes.

2. Narrative Reflection

Reflection encourages students to explore their interpretive thinking experiences. ${ }^{22}$ Itin $^{25}$ suggests that the action of education includes reflection, and Batalden and Davidoff ${ }^{10}$ write that experience without adequate reflection and conceptualization is a recipe for stagnation. Faculty agreed that reflective work deepens the understanding of the value and attitudes required for healthcare quality and patient safety work.

Reflection occurred throughout the course via designated discussion boards, team conference calls and a final written narrative describing the creative process, the team process and video production process. Requiring the students to focus on the same topic proved to be a wise choice as it provided the students and faculty common ground to challenge their assumptions and think through and interpret the various aspects of hand hygiene from multiple perspectives. The reflection process encouraged students to consider how the assignment allowed them to attain advanced KSAs competencies of evidence-based practice, teamwork and collaboration, and informatics. Student reflections included:

The relevance of this assignment for a quality and patient safety course initially eluded me. I quickly realized that I had little knowledge of the hand hygiene 
literature, clear communication was vital, and problem solving was ongoing. It was invaluable.

It was a great experience and allowed us to develop expression of content by video, rather than the traditional scholarly paper. We demonstrated great teamwork.

Overall I enjoyed the experience. As we continue to move forward in this highly technical society, it was especially significant for me to realize that I can keep up with the technology and that you are never too old or too experienced in this field to learn something new.

The assignment proved to be interesting and educational. I must admit that my own hand hygiene practice has improved as a result of this project.

The team demonstrated a good intergenerational group effort. Despite the distance among students we were able to work well together. Our weekly telephone conferences were effective in moving the project forward. This was an exercise in thinking outside the box.

3. Faculty Evaluation of Student Work

Faculty evaluation was based on assignment objectives including: 1) knowledge, as evidenced by a comprehensive evidence-based understanding of hand hygiene and the ability to distill the related components into the most salient form for the intended 
audience, 2) innovation and skill, as demonstrated by creative exploration and presentation of the topic, as well as success in capturing the topic for the selected audience, 3) impact, including the quality of expression, originality of concept and being memorable, 4) completeness, including credits or a list of cited works included at the end of the video, 5) attitude, as demonstrated by valuing continuous improvement of own communication and technology skills, and 6) dissemination plan. Faculty evaluation also included quality and completeness of peer reviews, as well as adherence to all deadlines. Table 2 outlines selected QSEN competencies and DNP student KSAs evaluation methods.

\section{Discussion}

There is minimal literature related to QSEN competency development or progression for DNP students, especially those enrolled in post-masters online distance education programs. The authors were unable to find literature related to successful QSEN competency integration in DNP programs, nor methods to help determine the extent to which these experienced students already possess the KSAs.

During the course planning phase, faculty conducted an extensive review of the literature. They found that active learning, such as this experiential innovation, is grounded in adult learning theory and promotes inquiry and skill in the process of knowledge acquisition with the emphasis on the process of learning by doing. Faculty were intrigued by the work of Scheckel and Ironside ${ }^{16}$ and as a result decided to "try something new" by creating an assignment for students to learn the QSEN KSA's and mindfully practice interpretive thinking - thinking that is analytic, reflective and multiperspective. 
The intrinsic value of a lesson results when learning is meaningful beyond the classroom. $^{27}$ To the delight of the authors, this assignment continues a life beyond the course, as students' partner with healthcare institutions, professional organizations and schools requesting to use, edit and package their videos. One team presented their video project at a national nursing conference and another partnered with the local chapter of a national organization that provided the funds to make copies and distribute the video as part of a community-outreach initiative. The authors also had the good fortune to present this innovative teaching-learning strategy during the inaugural 2010 QSEN National Forum in Denver.

\section{Lessons Learned}

The faculty learned that the time commitment for trying something new was substantial especially considering this was one of three assignments for the course. However, a significant amount of course planning occurred making the work manageable and relatively predictable. Students, most who were enrolled in a second course and all employed full time, remained positive and engaged, which is a testament to their flexibility and quest for learning.

This assignment can be replicated for a classroom based, hybrid or purely distance education DNP program. In so doing, the following items should be considered:

- Determine availability and access to video production equipment for recording and editing the projects. You may need to form the groups based on student access to equipment. Many cell phones can now record short video segments and there are free resources for assembling and editing video content.

- Identify a topic, skill or attitude relevant to the course or a specific target audience. This can be a topic the faculty has selected or the students can propose ideas and then 
vote on the one each group will actually pursue. Having all of the student groups address the same topic, skill or attitude is important to ensure students have equal access to the same resource pool and can be equally evaluated. The topic should also be something that can be accomplished in a reasonable time period. Each group can take a unique approach to the assignment.

- Instruct students to conduct a needs assessment of the target audience. They can personally interview people in the target audience or use the literature if it has already established the need for a specific group.

- Encourage students to storyboard their project. This process is easily accomplished using PowerPoint or other similar presentation tool where each of the slides/screens represents a specific screen. Students then write the dialog that goes along with that screen. Storyboards will help structure their recording tasks to make sure they get the content they need and don't waste time on unnecessary segments.

- Encourage students to meet with the instructor, teaching assistant or someone with production experience so they can explore ideas with this person for comments and suggestions. This can serve as a reality check for what is actually possible in this type of assignment and time frame. Students most common mistake is attempting to do much more than they can reasonably get done in time. Students should be encouraged to have at least three meetings (virtual, by phone or in person): an initial storyboard meeting, followed by a meeting while they're recording their scenes and then a final while they're editing their production. This will help keep students on track for completing on time.

\section{Summary}


While the literature on healthcare quality and patient safety is expanding, there is limited literature to guide effective multi-methods teaching strategies, especially in postmasters DNP online distance education programs. This article provides a description of a successful approach to integrate the QSEN competencies of teamwork and collaboration, evidence-based practice and informatics KSAs into an existing HCQPS course. Quality and safety competency development, especially in DNP education, must be broadly defined and take into consideration the often-substantial clinical experience of students. Such a view requires a different perspective of how and what is taught, within courses and across the curricula. Creative, multiple teaching strategies must be utilized so that students can transform experiences into existing cognitive frameworks, changing the way they think and behave.

\section{References}

1. American Association of Colleges of Nursing. The essentials of doctoral education for advanced nursing practice. Washington, DC:AACN; 2006.

2. American Association of Colleges of Nursing. Accessed http://www.aacn.nche.edu/DNP/DNPProgramList.htm on August 21, 2010.

3. Institute of Medicine. Health professions education: A bridge to quality. Washington, DC: National Academies Press; 2003. 
4. Cronenwett L, Sherwood G, Barnsteiner J, Disch J, Johnson J, Mitchell P, et al. Quality and safety education for nurses. Nurs Outlook 2007;55:122-31.

5. Cronenwett L, Sherwood G, Pohl J, Barnsteiner J, Moore S, Sullivan DT, et al. Quality and safety education for advanced nursing practice. Nurs Outlook 2009;57:338-348.

6. Pohl JM, Savrin C, Fiandt K, Beauchesne M, Drayton-Brooks S, Scheibmeir M, et al. Quality and safety in graduate nursing education: Cross-mapping QSEN graduate competencies with NONPF's NP core and practice doctorate competencies. Nurs Outlook 2009;57:349-354.

7. Hughes RG (ed.). Patient safety and quality: An evidence-based handbook for nurses. Rockville, MD: Agency for Healthcare Research and Quality;2008.

8. Epstein CD, Hovancsek MT, Dolan PL, Durner E, La Rocco N, Preiszig P, et al. Lights! camera! action!: Video projects in the classroom. J Nurs Educ 2003;42:558561.

9. Thompson DA, Cowan J, Holzmueller C, Wu AW, Bass E, Pronovost P. Planning and implementing a systems-based patient safety curriculum in medical education. American Journal of Medical Quality 2008;23:271-278. 
10. Batalden P, Davidoff F. Teaching quality improvement: the devil is in the details. JAMA 2007;298:1059-1061.

11. Kolb DA, Experiential learning: Experience as the source of learning and development. Englewood Cliffs, NJ: Prentice Hall; 1984.

12. Benner P, Sutphen M, Leonard V, Day L. Educating nurses: a call for radical transformation. San Francisco, CA: Josey-Bass; 2010.

13. Legg TJ, Adelman D, Mueller D, Levitt C. Constructivist strategies in online distance education in nursing. J Nurs Educ 2009;48:64-69.

14. Hunter JL, Krantz, S. Constructivism in cultural competence education. J Nurs Educ 2010;49:207-214.

15. Hughes M, Ventura S, Dando M. On-line interprofessional learning: introducting constructivism through enquiry-based learning and peer review. Journal of Interprofessional Care 2004;18:263-268.

16. Scheckel MM, Ironside PM. Cultivating interpretive thinking through enacting narrative pedagogy. Nurs Outlook 2006;54:159-165. 
17. Ironside PM. Using narrative pedagogy: learning and practicing interpretive thinking. Journal of Advanced Nursing 2006;55:478-486.

18. Larson E. Skin hygiene and infection prevention: More of the same or different approaches. Clinical Infectious Diseases 1999;29:1287-94.

19. Gould DJ, Chudleigh JH, Moralejo D, Drey N. Interventions to improve hand hygiene compliance in patient care. Cochrane Database of Syst Rev 2007(2):CD005186.

20. Kilpatrick C. Save lives: clean your hands. A global call for action at the point of care. Am J Infect Control 2009;37:261-62.

21. Anderson JL, Warren CA, Perez E, Louis RI, Phillips S, Wheeler J, et al. Gender and ethnic differences in hand hygiene practices among college students. Am J Infect Control 2008;36:361-368.

22. Morris J. Peer assessment: A missing link between teaching and learning? A review of the literature. Nurs Educ Today 2001;21:507-515.

23. Briggs LA, Heath J, Kelley J. Peer review for advanced practice nurses, What does it really mean? AACN Clinical Issues 2005;16:3-15. 
24. Little BB. The use of standards for peer review of online nursing courses: A pilot study. J Nurs Educ 2009; 48:411-415.

25. Boehm H. Bonnel W. The use of peer review in nursing education and clinical practice. Journal for Nurses in Staff Development 2010;26:108-115.

26. Itin CM. Reasserting the philosophy of experiential education as a vehicle for change in the $21^{\text {st }}$ century. The Journal of Experiential Education 1999;22:91-98.

27. McDonald LJ, Walters K. Collaborative teaching in a virtual environment to promote conceptual change for nurse educator master's students. Nurs Educ Perspect 2009;30:381-383.

Table 1. Student Video Peer Review Questions

\begin{tabular}{|l|l|}
\hline Video Title Name: & Select one response \\
\hline How well does the video meet the project requirements? & $1=$ incomplete \\
- $\quad$ Success in capturing the topic & $2=$ completely \\
- Quality of expression, being memorable & meets \\
- Originality of concept and general appeal & $3=$ exceptional \\
Comments: & \\
\hline
\end{tabular}




\begin{tabular}{|c|c|}
\hline $\begin{array}{l}\text { How well does the video meet the stated objectives of the authors? } \\
\text { Comments: }\end{array}$ & $\begin{array}{l}1=\text { incomplete } \\
2=\text { completely } \\
\text { meets } \\
3=\text { exceptional }\end{array}$ \\
\hline $\begin{array}{l}\text { Is the language and text in the video appropriate for the target } \\
\text { audience? } \\
\text { Comments: }\end{array}$ & $\begin{array}{l}1=\text { inappropriate } \\
2=\text { questionable } \\
3=\text { appropriate }\end{array}$ \\
\hline $\begin{array}{l}\text { Are there spelling or grammar mistakes in any of the content? } \\
\text { Comments: }\end{array}$ & $\begin{array}{l}1=\text { yes, it had error } \\
2=\text { no errors }\end{array}$ \\
\hline $\begin{array}{l}\text { Are the photographs and/or graphics in the video appropriate for the } \\
\text { target audience? } \\
\text { Comments: }\end{array}$ & $\begin{array}{l}1=\text { inappropriate } \\
2=\text { questionable } \\
3=\text { appropriate }\end{array}$ \\
\hline $\begin{array}{l}\text { Does the video engage the learner (e.g., encourage participation) in } \\
\text { anyway? } \\
\text { Comments: }\end{array}$ & $\begin{array}{l}1=\text { passive } \\
2=\text { enjoyable } \\
3=\text { engaging }\end{array}$ \\
\hline $\begin{array}{l}\text { How creative is the video? } \\
\text { Comments: }\end{array}$ & $\begin{array}{l}1=\text { not at all } \\
2=\text { somewhat } \\
3=\text { extremely }\end{array}$ \\
\hline Additional Thoughts and Comments: & \\
\hline
\end{tabular}

Table 2. Selected QSEN Competencies and DNP Student KSAs Evaluation Methods 


\section{QSEN Competency: Teamwork and Collaboration}

Definition: Function effectively with nursing and interprofessional teams, fostering open communication, mutual respect, and shared decision-making.

\begin{tabular}{|c|c|c|}
\hline Knowledge & Skills & Attitudes \\
\hline $\begin{array}{l}\text { Describe impact of own } \\
\text { communication style on } \\
\text { others* (Self Reflection and } \\
\text { Peer Review). }\end{array}$ & $\begin{array}{l}\text { Continuously plan for } \\
\text { improvement in use of self } \\
\text { in effective team } \\
\text { development and } \\
\text { functioning* (Self } \\
\text { Reflection and Peer } \\
\text { Review). } \\
\text { Solicit input from other } \\
\text { team members to improve } \\
\text { individual, as well as team, } \\
\text { performance* (Self } \\
\text { Reflection and Peer } \\
\text { Review). } \\
\text { Demonstrate skills in peer- } \\
\text { review that promote a } \\
\text { (Self-Reflection) }\end{array}$ & $\begin{array}{l}\text { Value different styles of } \\
\text { communication* (Self } \\
\text { Reflection and Peer } \\
\text { Review). } \\
\text { Respect the unique } \\
\text { attributes that members } \\
\text { bring to a team, including } \\
\text { variation in professional } \\
\text { orientations, competencies, } \\
\text { and accountabilities*(Self }\end{array}$ \\
\hline
\end{tabular}




\begin{tabular}{|c|c|c|}
\hline & $\begin{array}{l}\text { Demonstrate skills in } \\
\text { negotiating, consensus } \\
\text { building and partnering** } \\
\text { (Self Reflection and Peer } \\
\text { Review). }\end{array}$ & $\begin{array}{l}\text { Reflection and Peer } \\
\text { Review). }\end{array}$ \\
\hline \multicolumn{3}{|c|}{$\begin{array}{l}\text { QSEN Competency: Evidence-based Practice } \\
\text { Definition: Integrate best current evidence with clinical expertise }\end{array}$} \\
\hline Knowledge & Skills & Attitudes \\
\hline $\begin{array}{l}\text { Identify efficient and } \\
\text { effective search strategies to } \\
\text { locate reliable sources of } \\
\text { evidence* (Systematic } \\
\text { review of hand hygiene } \\
\text { literature). }\end{array}$ & $\begin{array}{l}\text { Exhibit contemporary } \\
\text { knowledge of best evidence } \\
\text { related to practice } \\
\text { specialty* (Systematic } \\
\text { review of hand hygiene } \\
\text { literature). } \\
\text { Disseminates evidence from } \\
\text { inquiry using multiple } \\
\text { methods to diverse } \\
\text { audiences** (Abstract } \\
\text { submissions and poster } \\
\text { presentations at national }\end{array}$ & $\begin{array}{l}\text { Value the need for } \\
\text { continuous improvement in } \\
\text { clinical practice based on } \\
\text { new knowledge* } \\
\text { (Systematic review of hand } \\
\text { hygiene literature, Self }\end{array}$ \\
\hline
\end{tabular}




\begin{tabular}{|l|l|l|}
\hline & $\begin{array}{l}\text { conferences and showing } \\
\text { videos at institutions and } \\
\text { organizations). }\end{array}$ & Reflection) \\
\hline
\end{tabular}

\section{QSEN Competency: Informatics}

Definition: Use information and technology to communicate, manage knowledge, mitigate error, and support decision-making.

\begin{tabular}{|c|c|c|}
\hline Knowledge & Skills & Attitudes \\
\hline $\begin{array}{l}\text { Contrast benefits and } \\
\text { limitations of common } \\
\text { information technology } \\
\text { strategies used in the } \\
\text { delivery of patient care* } \\
\text { (Self Reflection, Peer } \\
\text { Review, Video Production). }\end{array}$ & $\begin{array}{l}\text { Communicate the integral } \\
\text { role of information } \\
\text { technology in nurses' } \\
\text { work* (Self Reflection and } \\
\text { Peer Review). } \\
\text { Anticipate unintended } \\
\text { consequences of new } \\
\text { technology* (Self Reflection } \\
\text { and Peer Review). }\end{array}$ & $\begin{array}{l}\text { Appreciate the time, effort, } \\
\text { and skill required for } \\
\text { computers, databases, and } \\
\text { other technologies to } \\
\text { become reliable and } \\
\text { effective tools for patient } \\
\text { care* (Self Reflection, Peer } \\
\text { Review, Video Production }\end{array}$ \\
\hline
\end{tabular}




\begin{tabular}{|l|l|l|}
\hline & $\begin{array}{l}\text { scientific health information } \\
\text { appropriate for user need** }\end{array}$ & \\
(video production) & \\
\hline
\end{tabular}

*Taken from Cronenwett L, Sherwood G, Pohl J, Barnsteiner J, Moore S, Sullivan DT, et al. Quality and safety education for advanced nursing practice. Nurs Outlook 2009;57:338-348.

** Taken from Pohl JM, Savin C, Fiandt K, Beauchesne M, Drayton-Brooks, Scheibmeir M, et al. Quality and safety in graduate nursing education: cross mapping QSEN graduate competencies with NONPF's NP core and practice doctorate competencies. Nurs Outlook 2009;57:349-354.

NOTE: the authors used these as skill items, not knowledge items. 